latter dealt with mysteries, and membership was generally attained by virtue of a dream vision. The Omaha were a thoughtful and practical people. The idea of personality is dominant in the language and in the religious beliefs and practices. The force within this personality was recognised as that of the will, and "the Sacred Legend, which preserved the experiences of the years, emphasised the vital fact that better conditions are always attained by the exercise of thought, not by magical interferences." Enough has been said to show that Miss Fletcher has given us a monograph that deserves the careful study of all ethnologists, and will still further increase their indebtedness to the Bureau of American Ethnology.

A. C. HADDON.

THE ROYAI, MICROSCOPICAL SOCIETY.

O Wednesday, October 16, a conversazione was held in the Great Hall of King's College, about four hundred fellows and guests being received by the president, Mr. H. G. Plimmer, F.R.S., and Mrs. Plimmer. The object in view was, so far as practicable, to gather together a series of exhibits which would indicate the many uses, both in science and commerce, to which the microscope is put at the present time. In addition, the conversazione afforded an opportunity for those engaged in microscopic work to show objects of interest or to demonstrate the use of apparatus or appliances for special purposes.

The centre of the hall was occupied with pond life exhibits, about forty microscopes having been arranged on the tables under the direction of D. J. Scourfield, and these were a centre of interest to a considerable number of observers throughout the evening. Other interesting exhibits were some very beautiful botanical slides showing mitosis, by H. F. Angus and E. J. Sheppard; a Siedentopf ultra-microscope and cardioid condenser system for the observation of ultra-microscopic particles, by J. E. Barnard; an Abbe diffraction microscope illuminated by means of a quartz mercury-vapour lamp, by J. E. Barnard and Powell Swift; an instantaneous reflex photomicrographic camera, by F. W. Watson Baker; some preparations exhibiting Brownian movement, by G. P. Bate; a complete optical bench and an apparatus for polishing metal surfaces, by Conrad Beck; an extensive series of saccharomycetes, by A. Chaston Chapman; a very interesting old microscope and accessory apparatus, by Prof. A. Dendy, F.R.S.; some diffraction experiments, by J. W. Gordon; a series of foraminifera, by $\mathrm{E}$. Heron-Allen and A. Earland; microchemical reactions of a very striking character, by Prof. Herbert Jackson; an extremely beautiful series of photomicrographs in colour, by J. W. Ogilvy, and another series of stereophotomicrographs of water mites, also in colour, by H. Taverner. The possibility of applying his microspectra camera to the production of photomicrographs in colour was demonstrated by J. Rheinberg, and this exhibit attracted a great deal of attention.

Prof. Minchin, F.R.S., exhibited a series of trypanosomes which were of great interest. In the adjoining theatre, three lectures were delivered during the evening, Dr. E. J. Spitta giving a kinematographic exhibition of pond life, Prof. Hewlett lecturing on insects as carriers of disease, and Mr. Max Poser showing a beautiful series of liquid crystals by means of a projection micropolariscope, each of the lectures attracting a large audience. Apart from the social advantages of such a gathering, the exhibits were in all cases of real scientific interest, and demonstrated that the Royal Microscopical Society may look forward to doing an even greater work in the future than it has done in the past in bringing before scientific No. 2243 , vol. 9o] workers the possibilities of the use of the microscope. That the instrument is now a necessity in nearly all branches of science is, of course, well known, but it is often used merely as a tool and not as an appliance which demands considerable skill in its use for the best results to be obtained. If the council of the society should decide that this conversazione is to be but the first of a series of annual gatherings to be held with a similar object, then the success which has attended this function may be regarded as an indication that its usefulness in the future may be considerably increased.

\section{THE BRITISH ASSOCIATION AT DUNDEE. SECTION M.}

AGRICULTURE.

From the Opening Address by T. H. Middleton, M.A., President of the Section.

INTEREST in the practice of improved husbandry was first aroused in England by the books of Fitzherbert. The extent to which this author stimulated agriculture may be inferred from the appreciation with which his works were received in his own day, and copied by others for a century. He himself does not appear to have been acquainted with the classical writers. He describes the English practice with which he was familiar; he quotes frequently from the Scriptures and refers to early religious works, but only in writing of animal diseases, when he cites the "Sayinge of the Frenche man," is there any indication that he was influenced by foreign authors. Fitzherbert's "Boke of Husbandry" and "Surueyenge." while they are free from the direct influence of Roman writers, show us, nevertheless, that the English agriculture of his day owed much to Roman traditions. The careful business methods and accounting of the farm bailiffs of the Middle Ages, with which Thorold Rogers has acquainted us, were the methods which Fitzherbert learned and counselled, as they were the methods which Columella taught.

It was between 1523, when Fitzherbert's "Boke of Husbandry "was first printed, and 1557, when Tusser published his "Points of Good Husbandry," that the classical writers began to exert a direct influence on English farming. In 1532 there appeared Xenophon's "Treatise of Householde," "ryht counnyngly translated out of the Greke tonge into Englyshe by Gentian Hervet," which at once became popular and ran through a number of editions. At least as early as $1_{542}$ editions of the works on agriculture and gardening of Cato, Varro, Columella, and Palladius 1 were published in England, and they must certainly have been known to Tusser, for in his "Five Hundred Points of Good Husbandry," composed some years later, there is clear evidence of the influence of the writings of Xenophon and Columella. From the latter author Tusser adopts the method of a calendar, and he appears now and again to adapt Roman maxims to modern conditions. Thus in his calendar Columella says of March that it "is the proper time to cleanse meadows, and to defend and secure them from cattle; in warm and dry places indeed that ought to be done even from the month of January," and Tusser in his calendar for March rhymes :-

$$
\begin{aligned}
& \text { "Spare meadow at Gregorie Marshes at Pask } \\
& \text { for feare of drie Sommer no longer time ask } \\
& \text { Then hedge them and ditch them, bestow thereon pence, } \\
& \text { corne, meadow, and pasture aske alway good fence." }
\end{aligned}
$$

It might be, of course, that in discussing the same subject, a subject moreover which does not admit of much difference of opinion, the similarity of the above-

1 A translation of Palladius into English was made about $\mathrm{I4}_{42 \mathrm{O}}$ but it was not discovered and published until within recent times. 